Jurnal Akuntansi \& Perpajakan, Volume 1, No. 2, Januari 2020

\title{
PENGARUH ARUS KAS OPERASI, TINGKAT UTANG, DAN UKURAN PERUSAHAAN TERHADAP PERSISTENSI LABA
}

\author{
Mega Indriani ${ }^{1}$, Heinrych Wilson Napitupulu ${ }^{2}$ \\ Sekolah Tinggi Ilmu Ekonomi Jayakarta \\ Indrianimega47@gmail.com \\ nheinrych@gmail.com
}

\begin{abstract}
ABSTRAK
Penelitian ini bertujuan untuk menguji pengaruh arus kas operasi, tingkat utang dan ukuran perusahaan, terhadap persistensi laba. Variabel independen yang digunakan dalam penelitian ini arus kas operasi, tingkat utang dan ukuran perusahaan. Sedangkan variabel dependen dalam penelitian ini adalah persistensi laba.Penentuan sampel penelitian menggunakan metode purposive sampling dan memperoleh sampel sebanyak 5 perusahaan Property dan Real Estate selama periode 2016-2018 berdasarkan kriteria tertentu. Hasil penelitian menunjukkan bahwa uji t dan uji F Arus Kas Operasi dan Tingkat Utang berpengaruh signifikan persistensi laba, sedangkan ukuran perusahaan tidak berpengaruh signifikan terhadap Persistensi Laba.
\end{abstract}

Kata kunci: Arus Kas Operasi, Tingkat Utang, Ukuran Perusahaan, Persistensi Laba 
Jurnal Akuntansi \& Perpajakan, Volume 1, No. 2, Januari 2020

\section{PENDAHULUAN}

Perusahaan real estate dan property merupakan salah satu sector industri yang terdaftar di Bursa Efek Indonesia (BEI). Perkembangan industri real estate dan property begitu pesat saat ini dan akan semakin besar di masa yang akan datang. jumlah perusahaan real estate dan property yang terdaftar di BEI pada tahun 2016 berjumlah 46 perusahaan dan pada tahun 2018 terdapat 58 perusahaan.

Mengingat perusahaan yang bergerak pada sektor real estate dan property tersebut adalah perusahaan yang sangat peka terhadap pasang surut perekonomian, maka seiring perkembangannya sektor real estate dan property dianggap menjadi salah satu sektor yang mampu bertahan dari kondisi ekonomi secara makro di Indonesia. Terbukti dengan semakin banyaknya sektor real estate dan property yang memperluas landbank (aset berupa tanah), melakukan ekspansi bisnis, dan hingga tahun 2019 sektor real estate dan property yangterdaftar di BEI bertambah menjadi 64 perusahaan. Fenomena umum di atas pertumbuhan laba sektor property, real estate, mengalami penurunan khususnya di tahun 2018 (Laras Agustin, 2018). Penurunan laba tersebut disebabkan beberapa faktor diantaranya nilai tukar rupiah terhadap dolar, suku bunga dan faktor perekonomian Indonesia. Faktorfaktor tersebut selain memengaruhi daya beli masyarakat, juga memengaruhi kegiatan perusahaan operasi perusahaan misalnya melemahnya nilai tukar rupiah terhadap dolar menyebabkan harga bahan material naik dikarenakan bahan material yang digunakan dalam pengembangan property berasal dari bahan material impor. Selain itu kenaikan kurs ini menyebabkan beban gaji karyawan dan beban operasi naik. Sementara untuk suku bunga yang besar memengaruh perusahaan saat melakukan peminjaman dari bank, mengingat bisnis property ini membutuhkan biaya yang besar dalam proses pengembangan property.

Besarnya peminjaman dana akan membebani perusahaan dalam melakukan pelunasan utang dikarenakan bunga yang cukup besar. Selain itu di pihak konsumen besarnya suku bunga membebani konsumen dalam membiayai properti yang akan dibeli. Fenomena di atas hanya menjelaskan penyebab penurunan pertumbuhan perusahaan property dan real estate secara umum. Dalam penelitian ini faktor-faktor yang memengaruhi persistensi laba adalah arus kas operasi, tingkat utang, dan ukuran perusahaan. Faktor arus kas operasi diperoleh dari kas yang diterima dari pelanggan, piutang, dan dividen. Pengukuran tersebut dilakukan untuk mengetahui besarnya tingkat arus kas, jika nilai arus kas besar maka hal tersebut menjelaskan bahwa arus kas mengalami fluktuasi sehingga laba tidak persisten.

Penelitian-penelitian sebelumnya mengenai persistensi laba sebagai variabel dependen telah banyak dilakukan, di antaranya peneliti yang terkait dengan volatilitas arus dilakukan oleh (Briliana Kusuma dan R.Arja Sadjiarto 2017), (Celindra 2017) berdasarkan penelitian tersebut volatilitas berpengaruh signifikan terhadap persistensi laba, semakin tinggi volatilitas arus kas maka laba tidak akan persisten. Sementara penelitian yang dilakukan oleh (Destra Afri Sulastri, 2017) 
Jurnal Akuntansi \& Perpajakan, Volume 1, No. 2, Januari 2020

dan (Britari Mutia Anggraeni, 2018) volatilitas arus kas tidak berpengaruh terhadap persistensi laba.

Faktor leverage dihitung dengan debt to asset ratio. Selain itu sektor perusahaan property dan real estate dalam melakukan kegiatan operasi perusahaan membutuhkan modal yang besar salah satu modal tersebut adalah utang. Perhitungan tersebut dilakukan untuk menilai seberapa besar asset perusahaan dibiayai oleh utang. Jika rasionya tinggi artinya pendanaan utang semakin banyak dan akan sulit memperoleh tambahan pinjaman jika kinerja perusahaan menurun. Dikhawatirkan perusahaan tidak mampu menutupi utangnya dengan aset yang dimilikinya. Tetapi besarnya tingkat leverage menyebabkan perusahaan mempertahankan kinerja yang baik di mata investor, dengan kinerja yang baik maka kreditor memiliki kepercayaan dalam memberikan dananya kepada perusahaan. Penelitian yang terkait leverage dilakukan oleh Rina Malahayati, Muhammad Arfan, dan Hasan Basri (2018). Btari Mutia Anggraeni (2017) dalam penelitian tersebut tingkat leverage berpengaruh signifikan terhadap persistensi laba. Besarnya tingkat leverage menyebabkan perusahaan meningkatkan persistensi laba dengan tujuan mempertahankan kinerja, dengan kinerja yang baik maka diharapkan memiliki kepercayaan terhadap perusahaan, dan perusahaan akan mudah memperoleh dana. Sementara dalam penelitian Briliana Kusuma dan R Arja Sadarto (2017), Destra Afri Sulastri (2017) leverage tidak berpengaruh terhadap persistensi laba. Sementara untuk penelitian Rina Malayati, Muhammad Arfan, dan Hasan Basri (2018) berjudul Pengaruh Ukuran Perusahaan, Financial Leverage terhadap Persistensi Laba dan Dampaknya terhadap Kualitas Laba. Hasil penelitian tersebut menunjukan ukuran perusahaan dan financial leverage berpengaruh terhadap persistensi laba. Ukuran perusahaan berpengaruh signifikan terhadap kualitas laba, sementara financial leverage tidak berpengaruh terhadap kualitas laba. secara stimultan ukuran perusahaan dan financial leverage berpengaruh terhadap persistensi. Secara simultan ukuran perusahaan dan financial leverage berpengaruh terhadap kualitas laba. Faktor ukuran perusahaan dihitung dengan logaritma terhadap asset perusahaan, perhitung tersebut untuk menilai besarnya ukuran perusahaan berdasarkan asset yang dimilikinya. Asset merupakan harta yang dimiliki oleh perusahaan meliputi kas, piutang, persediaan, asset lancar, dan aset tidak lancar.

Semakin besar aset perusahaan maka semakin besar pula ukuran perusahaan tersebut. Ukuran perusahaan yang besar mampu menghasilkan laba yang persisten. Penelitian yang terkait dengan ukuran perusahaan dilakukan oleh Mety Nuraini dan Agus Purwanto (2017), Btari Mutia Anggraeni (2018), Rina Malahayati, Muhammad Arfan, dan Hasan Basri (2018) dalam penelitian tersebut ukuran perusahaan berpengaruh signifikan terhadap persistensi laba, semakin besar ukuran perusahaan maka laba akan persisten. Dan penelitian oleh Dewi dan Putri (2018) yang memperoleh hasil ukuran perusahaan berpengaruh positif terhadap persistensi laba. Sedangkan menurut Mir'atul Khairoh (2018) ukuran perusahaan tidak berpengaruh terhadap persistensi laba. 
Jurnal Akuntansi \& Perpajakan, Volume 1, No. 2, Januari 2020

Perbedaan penelitian ini dengan penelitian sebelumnya yaitu pada objek penelitian. Penelitian ini dilakukan pada perusahaan property dan real estate yang terdaftar di bursa efek Indonesia periode 2016-2018. Alasan peneliti memilih perusahaan property dan real estate disebabkan karena pada saat ini pertumbuhan property dan real estate sedang mengalami penurunan yang disebabkan oleh pengaruh ekonomi negara digunakan sebagai bahan penelitian. Alasan penulis hanya mengambil variabel arus kas operasi, tingkat hutang dan ukuran perusahaan, karena dari penelitianpenelitian sebelumnya ketiga variabel tersebut berpengaruh signifikan terhadap persistensi laba dan penulis ingin mencari tahu seberapa besar pengaruh ketiga variabel tersebut terhadap persistensi laba pada Perusahaan Property dan Real Estate periode 2016-2018. Tujuan penelitian ini adalah untuk mengetahui pengaruh arus kas operasi terhadap persistensi laba pada perusahaan property dan real estate, mengetahui pengaruh tingkat utang terhadap persistensi laba pada perusahaan property dan real estate, untuk mengetahui pengaruh ukuran perusahaan terhadap persistensi laba pada perusahaan property dan real estate. Dan juga untuk mengetahui pengaruh arus kas, tingkat utang, ukuran perusahaan secara simultan terhadap persistensi laba pada perusahaan property dan, real estate.

\section{KAJIAN LITERATUR}

Menurut Ikatan Akuntansi Indonesia dalam Pernyataan Standar Akuntansi Keuangan No.2 Tahun 2018 pengertian arus kas adalah: "Informasi arus kas memberikan dasar bagi pengguna laporan keuangan untuk menilai kemampuan entitas dalam menghasilkan kas dan setara kas dan kebutuhan entitas dalam menggunakan arus kas tersebut." Menurut Kieso et al. (2017: 21), pengertian arus kas adalah: "The statement of cash is a primary statements that reports the cash receipt, cash payment and net change resulting form the operating, investing and financial activities of an enterprise during a period."

Dari beberapa definisi di atas, dapat disimpulkan bahwa arus kas merupakan informasi tentang arus yang keluar dan masuk yang berasal dari kegiatan operasi, pendanaan, dan investasi pada suatu periode tertentu. Menurut Dwi Martani (2017: 384), secara umum laporan arus kas terdiri dari tiga bagian, yang merupakan karakteristik transaksi kas perusahaan, yaitu sebagai berikut:

a. Aktivitas Operasi (Operating Activities), merupakan transaksi-transaksi kegiatan operasional yang dilaporkan dalam laba rugi. Karena transaksi operasional ini sifatnya jangka pendek, akun-akun utama dalam aset lancar nonkas dan liabilitas lancar juga terkait dengan arus kas aktivitas operasi.

b. Aktivitas Investasi (Investing Activities), merupakan transaksi-transaksi yang terkait dengan perubahan aset nonlancar, termasuk investasi dan aset- aset tak berwujud.

c. Aktivitas Pendanaan (financing activities), merupakan transaksi-transaksi yang terkait dengan liabilitas jangka panjang dan ekuitas perusahaan sebagai sumber pendanaan utama perusahaan.

Menurut Wareen etal. (Damayanti Dian, 2018: 53), yang dimaksud dengan utang adalah: "Kewajiban untuk membayar 
Jurnal Akuntansi \& Perpajakan, Volume 1, No. 2, Januari 2020

sesuatu yang dicatat sebagai kewajiban kepada perusahaan, bank, atau individu yang memberikan pinjaman."

Menurut Irham Fahmi (2016: 160)

utang dibagi ke dalam dua golongan, yaitu Current Liabilities atau Short-term Liabilities (utang jangka pendek) atau utang lancar, dan Non Current Liabilities atau Long-term Liabilities (utang jangka panjang).

Untuk menjalankan operasinya setiap perusahaan memiliki berbagai kebutuhan, terutama yang berkaitan dengan dana agar perusahaan dapat berjalan sebagaimana mestinya. Dana selalu dibutuhkan untuk menutupi seluruh atau sebagian dari biaya yang diperlukan. Dana juga dibutuhkan untuk melakukan ekspansi atau perluasan usaha atau investasi baru. Artinya di dalam perusahaan harus tersedia dana dalam jumlah tertentu sehingga tersedia pada saat dibutuhkan.Dalam praktiknya untuk menutupi kekurangan akan kebutuhan dana, perusahaan memiliki beberapa sumber dana yang dapat digunakan. Sumber- sumber dana secara garis besar dapat diperoleh dari modal sendiri atau pinjaman haruslah digunakan beberapa perhitungan yang matang yakni dengan menggunakan leverage ratio. Menurut Agus Sartono (2016: 120), "Financial leverage adalah: Rasio yang menunjukan proporsi atas penggunaan utang untuk membiayai investasinya. Perusahaan yang tidak mempunyai leverage berarti menggunakan modal sendiri $100 \%$."

Dari beberapa definisi di atas dapat disimpulkan bahwa leverage ratio adalah rasio yang digunakan untuk mengukur sejauh mana aktiva perusahaan dibiayai dengan utang. Artinya besarnya jumlah utang yang digunakan perusahaan untuk membiayai kegiatan usahanya dibandingkan dengan menggunaklan modal sendiri. beberapa tujuan perusahaan dengan menggunakan Leverage Ratio menurut Kasmir (2017: 153) adalah Untuk mengetahui posisi perusahaan terhadap kewajiban kepada pihak lainnya (kreditor). Untuk menilai keseimbangan antara nilai aktiva khususnya aktiva tetap dengan modal. Untuk menilai kemampuan perusahaan dalam memenuhi kewajiban yang bersifat tetap (seperti angsuran pinjaman termasuk bunga). Untuk menilai seberapa besar aktiva perusahaan yang dibiayai oleh utang. Untuk menilai seberapa besar pengaruh utang perusahaan terhadap pengelolaan aktiva. Untuk menilai atau mengukur berapa bagian dari setiap rupiah modal sendiri yang dijadikan jaminan utang jangka panjang. Untuk menilai berapa dana pinjaman yang segera akan ditagih, terdapat sekian kalinya modal sendiri yang dimiliki.

Debt to assets ratio merupakan rasio utang yang digunakan untuk mengukur perbandingan antara total utang dengan total aktiva. Dengan kata lain, seberapa besar aktiva perusahaan dibiayai oleh hutang atau seberapa besar utang perusahaan berpengaruh terhadap pengelolaan aktiva. Debt to assets ratio dapat dihitung dengan menggunakan rumus sebagai berikut:

$$
\mathrm{DAR}=\frac{\text { TotalDebt }}{\text { TotalAsset }}
$$

Debt to equity ratio merupakan rasio yang digunakan untuk menilai utang dengan ekuitas. Rasio ini dicari dengan cara membandingkan antara seluruh utang, termasuk utang lancar dengan seluruh ekuitas. Rasio ini berguna untuk 
Jurnal Akuntansi \& Perpajakan, Volume 1, No. 2, Januari 2020

mengetahui jumlah dana yang disediakan peminjam (kreditor) dengan pemilik perusahaan. Dengan kata lain, rasio ini berfungsi untuk mengetahui setiap rupiah modal sendiri yang dijadikan untuk jaminan utang. Debt to equity ratio dapat dihitung dengan menggunakan rumus sebagai berikut:

$$
\mathrm{DER}=\frac{\text { TotalDebt }}{\text { Equity }}
$$

Time interest earned merupakan rasio untuk mencari jumlah kali perolehan bunga. Untuk mengukur rasio ini, digunakan perbandingan antara laba sebelum bunga dan pajak dibandingkan dengan biaya bunga yang dikeluarkan. Rumus untuk mencari time interest earned yaitu:

Time Interest Earned $=\frac{\text { EBIT }}{\text { Beban Bunga }}$

Fixed changed coverage atau lingkup biaya tetap merupakan rasio yang menyerupai time interest earned ratio. Hanya saja perbedaannya adalah rasio ini dilakukan apabila perusahaan memperoleh utang jangka panjang atau menyewa aktiva berdasarkan kontrak sewa (lease contract). Rumusan untuk mencari fixed charged coverage adalah sebagai berikut:

Fixed Charg e Coverage $=\frac{(\mathrm{EBT}+\text { Interest }+ \text { Lease }}{(\text { Interest }+ \text { Lease })}$

Menurut Bambang Riyanto (2017: 305) ukuran perusahaan adalah: "Ukuran perusahaan menggambarkan besar kecilnya suatu perusahaan yang ditunjukkan pada total aktiva, jumlah penjualan, rata-rata penjualan."

Salah satu komponen dari kualitas laba adalah persistensi laba. Persistensi laba akuntansi adalah revisi dalam laba akuntansi yang diharapkan di masa depan (expected future earnings) yang diimplikasi oleh laba akuntansi tahun berjalan (Djamaluddin, dalam Nurul 2019: 46).

Menurut Penman dan Zhang (Salsabiila, Pratomo, dan Nurbaiti, 2018: 113), persistensi laba adalah: "Persistensi laba merupakan laba yang mempunyai kemampuan sebagai indikator laba periode mendatang (future earnings) yang dihasilkan secara berulang-ulang (repetitive) dalam jangka panjang (sustainable)."

Dalam penelitian ini dirumuskan untuk menggambarkan hubungan atau pengaruh antara dua macam variabel yaitu variabel bebas Arus Kas Operasi (X1), Tingkat Utang (X2), Ukuran Perusahaan (X3), terhadap variabel terikat Persistensi Laba (Y) pada Perusahaan Property dan Real Estate yang Terdaftar di BEI pada Tahun 2016-2018. Perumusan hipotesis ini dilakukan untuk mengetahui hubungan antara Arus Kas Operasi, Tingkat Utang dan Ukuran Perusahaan terhadap Persistensi Laba.

Hasil hipotesis masing-masing variabel dapat dilihat sebagai berikut:

$\mathrm{H}_{1}$ : Terdapat pengaruh Arus Kas Operasi terhadap Persistensi Laba.

$\mathrm{H}_{2}$ : Terdapat pengaruh Tingkat Utang terhadap Persistensi Laba.

$\mathrm{H}_{3}$ : Terdapat pengaruh Ukuran Perusahaan terhadap Persistensi Laba.

$\mathrm{H}_{4}$ : Terdapat pengaruh Arus Kas Operasi, Tingkat Utang, dan Ukuran Perusahaan secara simultan terhadap Persistensi Laba. 
Jurnal Akuntansi \& Perpajakan, Volume 1, No. 2, Januari 2020

\section{METODE}

Definisi operasional menjelaskan cara tertentu yang digunakan untuk meneliti dan mengoperasikan konstrak, sehingga memungkinkan bagi peneliti yang lain untuk melakukan replica pengukuran dengan cara yang sama atau mengembangkan cara pengukuran konstrak yang lebih baik. Dengan demikian terdapat definisi yang jelas dan tepat untuk memberikan pengertian terhadap definisi yang jelas dan tepat untuk memberikan pengertian terhadap variabel-variabel yang digunakan yaitu:

\section{Variabel Bebas}

Variabel bebas (Independent variable) adalah variabel yang menjelaskan atau memengaruhi variabel terikat (Dependent variable). Di dalam penelitian ini variabel independennya adalah Arus kas operasi, Tingkat utang, Ukuran Perusahaan.

\section{a. Arus Kas Operasi $\left(\mathrm{X}_{1}\right)$}

Seluruh transaksi penerimaan kas berkaitan dengan pendapatan dan seluruh pengeluaran kas berkaitan dengan biaya operasi dan bukan merupakan aktivitas investasi dan aktivitas pendanaan (Subramanyam,2016:98)

Likuiditas dapat diukur dengan rumus sebagai berikut:

$$
\mathrm{AKO}=\frac{\text { Arus Kas Operasi }}{\text { Kewajiban Lancar }}
$$

b. Tingkat Utang $\left(\mathrm{X}_{2}\right)$

Kewajiban untuk membayar sesuatu yang dicatat sebagai kewajiban kepada perusahaan, bank, atau individu yang memberikan pinjaman (Wareen etal, 2016:53).

Tingkat utang dapat diukur dengan rumus sebagai berikut:

$$
\text { DAR }=\frac{\text { Total Debt }}{\text { total aset }}
$$

c. Ukuran Perusahaan $\left(\mathrm{X}_{3}\right)$

Ukuran perusahaan merupakan salah satu karakteristik perusahaan yang merupakan variabel penduga dan banyak digunakan untuk menjelaskan variasi pengungkapan dalam laporan tahunan perusahaan. Ukuran perusahaan menggambarkan seberapa besar aset yang dimiliki perusahaan.

Ukuran perusahaan suatu skala dimana dapat diklasifikasikan besar kecilnya perusahaan menurut berbagai cara, yaitu: total assets, log size, nilai pasar saham dan lain. (Jogiyanto, 2017:280). Dengan rumus sebagai berikut:

$$
\text { Size }=\text { Ln (total aset) }
$$

\section{Variabel Terikat}

Creswell (2015: 238) menjelaskan, "Variable terikat (dependen) merupakan variable yang dipengaruhi atau yang menjadi akibat karena adanya variable bebas." Menurut Sugiono (2015: 39), "Variabel dependen sering disebut sebagai variabel output, kriteria, konsekuen. Dalam bahasa Indonesia sering disebut sebagai variabel terikat. Variable terikat merupakan variabel yang dipengaruhi atau menjadi akibat, karena adanya variabel bebas." Dalam penelitian ini yang menjadi variable terikat adalah Persistensi Laba. Earnings persistence is the current earning is expected to persist into the future, since 
Jurnal Akuntansi \& Perpajakan, Volume 1, No. 2, Januari 2020

current earning then provide a better indication of future firm performace. (Scott, 2016: 155)

$$
\frac{\text { PTBI }_{t+1}}{\text { Rata - rata Total Aset }}
$$

PTBI $_{t+1}=$ Laba akuntansi sebelum pajak periode mendatang.

\section{HASIL DAN PEMBAHASAN}

Perusahaan yang dijadikan sampel dalam penelitian ini untuk setiap tahunnya berada di perusahaan yang sama, hal ini terjadi karena kriteria semua perusahaan harus menghasilkan laba untuk setiap tahunnya. Berdasarkan kriteria di atas, maka perusahaan yang dijadikan sampel penelitian sebanyak 18 perusahaan yang terdaftar di Bursa Efek Indonesia. Dalam penelitian ini, hanya diambil 18 perusahaan property dan real estate yang dipilih berdasarkan kriteria yang telah ditetapkan.

\begin{tabular}{|c|l|}
\hline No & \multicolumn{1}{|c|}{ Nama Emiten } \\
\hline 1 & PT Gading Development Tbk \\
\hline 2 & $\begin{array}{l}\text { PT Gowa Makassar Tourism } \\
\text { Development Tbk }\end{array}$ \\
\hline 3 & PT Jaya Real Property Tbk \\
\hline 4 & PT Plaza Indonesia Realty Tbk \\
\hline 5 & PT Roda Vivatex Tbk \\
\hline
\end{tabular}

Statistik deskriptif dari masingmasing variable penelitian. Nilai minimum arus kas operasi menunjukkan bahwa kemampuan perusahaan dalam menghasilkan kas dan setara kas, dan memungkinkan para pemakai mengembangkan model untuk menilai dan membandingkan nilai sekarang dari arus kas masa depan paling rendah sebesar 0,079. Sedangkan nilai maksimum menunjukkan bahwa kemampuan perusahaan dalam menghasilkan kas dan setara kas, dan memungkinkan para pemakai mengembangkan model untuk menilai dan membandingkan nilai sekarang dari arus kas masa depan paling tinggi sebesar 2,131. Secara keseluruhan perusahaan dalam penelitian ini memiliki nilai rata-rata sebesar 0,588 yang menunjukkan bahwa rata-rata kemampuan perusahaan dalam menghasilkan kas dan setara kas, dan memungkinkan para pemakai mengembangkan model untuk menilai dan membandingkan nilai sekarang dari arus kas masa depan sebesar 0,588. Sedangkan nilai standar deviasi adalah 0,719 menunjukkan bahwa kemampuan perusahaan dalam menghasilkan kas dan setara kas, dan memungkinkan para pemakai mengembangkan model untuk menilai dan membandingkan nilai sekarang dari arus kas masa depan hampir sama.

Tingkat Utang dalam penelitian ini memiliki nilai minimum yang menunjukkan bahwa kewajiban perusahaan yang harus dibayarkan kepada pihak ketiga saat jatuh tempo paling rendah sebesar 0,001. Sedangkan nilai maksimum menunjukkan bahwa kewajiban perusahaan yang harus dibayarkan kepada pihak ke tiga saat jatuh tempo paling tinggi sebesar 0,051. Secara keseluruhan perusahaan dalam penelitian ini memiliki nilai rata-rata sebesar 0,017, yang menunjukkan bahwa rata-rata utang perusahaan yang harus dibayarkan kepada pihak ketiga saat jatuh tempo sebesar 0,017. Sedangkan nilai standar deviasi adalah 0,015 menunjukkan bahwa kewajiban perusahaan yang harus dibayarkan kepada pihak ke tiga saat jatuh tempo hampir sama. 
Jurnal Akuntansi \& Perpajakan, Volume 1, No. 2, Januari 2020

Ukuran Perusahaan memiliki nilai rata-rata sebesar 28,719 dengan nilai minimun 27,035 dan maksimum 29,986. Nilai minimun sebesar 27,035 menunjukkan bahwa terdapat perusahaan yang memiliki jumlah aset paling rendah. dibandingkan perusahaan lainnya yang terdapat dalam penelitian ini, perusahaan tersebut yaitu PT Roda Vivatex Tbk. Sedangkan nilai maksimum sebesar 29,986 menunjukkan bahwa terdapat perusahaan yang memiliki jumlah aset paling tinggi dibandingkan dengan perusahaan lainnya yang terdapat dalam penelitian ini, perusahaan tersebut yaitu PT Jaya Real Property Tbk. Nilai sebesar 28,719 menunjukkan bahwa rata-rata perusahaan yang terdapat dalam penelitian ini memiliki jumlah asset yang cenderung tinggi. Sedangkan nilai standar deviasi adalah 0,955 menunjukkan bahwa ukuran perusahaan dalam penelitian ini cukup beragam.

Persistensi Laba memiliki nilai rata-rata sebesar 0,890 dengan nilai minimun sebesar 0,053 dan maksimum sebesar 3,018. Nilai minimum tersebut menunjukkan bahwa dari seluruh perusahaan yang terdapat dalam penelitian ini terdapat perusahaan yang memiliki nilai persistensi laba paling rendah yakni 0,053 perusahaan tersebut yaitu PT Gading Development Tbk akan tetapi, perusahaan tersebut masih dikatakan memiliki laba yang persisten karena nilai minimum tersebut berada di atas angka 0. Sedangkan nilai maksimum sebesar 3,018 menunjukkan bahwa dari sekian perusahaan dalam penelitian ini terdapat perusahaan yang memiliki nilai persistensi laba paling tinggi dan secara otomatis perusahaan tersebut dikatakan memiliki laba yang sangat persisten (high persisten). Secara keseluruhan perusahaan dalam penelitian ini memiliki laba yang persisten karena memiliki nilai rata-rata di atas angka 0 yakni 0,890. Sedangkan nilai standar deviasi adalah 0,979 menunjukkan bahwa nilai persistensi laba perusahaan dalam penelitian ini hampir sama.

\section{a. Uji Normalitas}

Bahwa batang histogram mirip dengan bentuk kurva normal, yaitu berbentuk seperti lonceng. Hal ini membuktikan bahwa distribusi tersebut sudah dapat dikatakan normal atau mendekati normal. Selanjutnya di bawah ini dipaparkan gambar uji normalitas, yaitu gambar Normal Probability Plot:

\section{b. Uji Multikolinieritas}

Hasil perhitungan nilai tolerance menunjukan semua variabel bebas memiliki nilai tolerance mendekati angka 1 dan nilai Variance Inflation Factor (VIF) diatas angka 1 . Sehingga dapat disimpulkan bahwa tidak terjadi multikolinieritas atau bebas multikolinieritas

\section{c. Uji Autokorelasi}

Berdasarkan hasil bahwa nilai Durbin Watson $(\mathrm{DW})=2.010$. Sedangkan nilai 4 $\mathrm{d}_{\mathrm{U}}=4-1.7501=2.2499$.

Dengan demikian $\mathrm{DW}>\mathrm{d}_{\mathrm{L}}$ atau $2.010>0.8140$ dan DW $<(4-\mathrm{du})$ atau $2,010<2.2499$. Dengan demikian $\mathrm{dL}<\mathrm{DW}<4-$ du atau $0.8140<$ $2.010<2.2499$ berarti berada pada daerah tidak ada autokorelasi, terima hipotesis.

\section{d. Uji Heteroskedastisitas}


Jurnal Akuntansi \& Perpajakan, Volume 1, No. 2, Januari 2020

Hasil uji glejser menunjukkan bahwa nilai signifikansi dari kelima variabel menunjukkan > 0,05 yang berarti tidak terjadi heteroskedastisitas pada model regresi, sehingga model regresi layak dipakai untuk mengetahui persistensi laba berdasar masukan dari variabel independennya.

\section{e. Uji Regresi Linier Berganda}

Diketahui persamaan regresi adalah sebagai berikut:

$$
\begin{aligned}
& Y=a+b_{1} X_{1}+b_{2} X_{2}+b_{3} X_{3}+e \\
& Y=-6,182+1,030 X_{1}+41,899 X_{2}+ \\
& 0,203 X_{3}
\end{aligned}
$$

Keterangan:

a. Nilai konstanta a $=-6,184$ memberikan arti bahwa jika variabel bebas diabaikan atau dengan kata lain jika tidak ada variasi pada arus kas operasi, tingkat utang, dan ukuran perusahaan maka persistensi laba akan bernilai 6,184.

b. Nilai koefisien $b_{1}=1,030$ hal ini berarti bahwa setiap peningkatan satu satuan pada arus kas operasi dengan asumsi variabel, tingkat utang dan ukuran perusahaan, maka persistensi laba akan mengalami peningkatan sebesar 1,030 satuan dan bergerak ke arah yang sama (arah positif).

c. Nilai koefisien $b_{2}=41,899$ hal ini berarti bahwa setiap peningkatan satu satuan pada tingkat utang dengan asumsi variabel arus kas operasi dan ukuran perusahaan, maka persistensi laba akan mengalami peningkatan sebesar 41,899 satuan dan bergerak ke arah yang sama (arah positif).

d. Nilai koefisien $b_{3}=0,203$ hal ini berarti bahwa setiap peningkatan satu satuan pada ukuran perusahaan dengan asumsi variabel arus kas operasi, tingkat utang, maka persistensi laba akan mengalami peningkatan sebesar 0,203 satuan dan bergerak ke arah yang sama (arah positif).

\section{f. Analisis Koefisien Korelasi}

Nilai koefisien korelasi antara Arus Kas Operasi $\left(\mathrm{X}_{1}\right)$ dengan Persistensi Laba (Y) sebesar 0,588 yang menunjukan korelasi cukup kuat karena berada pada interval $(0,400-0,600)$. Nilai koefisien korelasi antara Tingkat Utang $\left(\mathrm{X}_{2}\right)$ dengan Persistensi Laba (Y) sebesar 0,514 yang menunjukan korelasi cukup kuat karena berada pada interval $(0,400-0,600)$. Nilai koefisien korelasi antara Ukuran Perusahaan $\left(\mathrm{X}_{3}\right)$ dengan Persistensi Laba (Y) sebesar -0,197 yang menunjukan korelasi bersifat sangat lemah karena berada pada interval $(-0,20$ s.d 0,00$)$.

\section{g. Analisis Uji Hipotesis}

Berdasarkan tabel di atas bahwa nilai $\mathrm{t}$ hitung > t tabel atau 4,612 > 2,16037 dan nilai probabilitas atau signifikansi $0,000<$ 0,05 . Maka dapat disimpulkan bahwa maka Ho ditolak dan Ha diterima. Hal ini berarti bahwa Arus Kas Operasi berpengaruh terhadap Persistensi Laba. Berdasarkan tabel di atas bahwa nilai $\mathrm{t}$ hitung $>\mathrm{t}$ tabel atau 4,246 > 2,16037 dan nilai probabilitas atau signifikansi $0,001<0,05$. Maka dapat disimpulkan bahwa maka Ho ditolak dan Ha diterima. Hal ini berarti bahwa Tingkat Utang berpengaruh terhadap Persistensi Laba. Berdasarkan tabel di atas bahwa nilai t hitung $<\mathrm{t}$ tabel atau 1,193 < 2,16037 dan nilai probabilitas atau signifikansi $0,258>$ 0,05. Maka dapat disimpulkan bahwa maka 
Jurnal Akuntansi \& Perpajakan, Volume 1, No. 2, Januari 2020

Ho diterima dan Ha ditolak. Hal ini berarti bahwa Ukuran Perusahaan tidak berpengaruh terhadap Persistensi Laba. Berdasarkan tabel di atas bahwa nilai $\mathrm{F}$ hitung > F tabel atau 11,111> 3,590 dan nilai probabilitas atau signifikansi $0,001<$ 0,05. Maka dapat disimpulkan bahwa: Arus Kas Operasi, Tingkat Utang dan Ukuran Perusahaan dapat untuk memprediksi variabel Persistensi Laba.

\section{h. Analisis Koefisien Determinasi}

Dalam penelitian ini menggunakan tiga variable bebas sehingga koefisien determinasi adalah Adjusted $\mathrm{R}$ Square $\left(\mathrm{R}^{2}\right)$. Tabel di atas menghasilkan nilai koefisien determinasi atau Adjusted $\mathrm{R}$ Square $\left(\mathrm{R}^{2}\right)=$ 0.684. Dengan demikian besarnya Arus Kas Operasi, Tingkat Utang dan Ukuran Perusahaan terhadap Persistensi Laba adalah sebesar $68,4 \%$ sedangkan sisanya $31,6 \%$ dipengaruhi oleh faktor-faktor lainnya yang tidak diteliti.

\section{KESIMPULAN}

Variabel Arus Kas Operasi berpengaruh terhadap Persistensi Laba, arus kas operasi merupakan faktor yang mempengaruhi tinggi rendahnya persistensi laba perusahaan. Semakin tinggi arus kas operasi sebuah perusahaan maka akan semakin tinggi pula tingkat persistensi labanya. Informasi arus kas operasi perusahaan dapat dijadikan alat pengecekan atas informasi laba dan sebagai pengukur kinerja perusahaan.

$$
\text { Variabel Tingkat Utang }
$$
berpengaruh terhadap Persistensi Laba, tingkat utang akan memberikan sinyal positif bagi investor. Tingkat utang berpengaruh terhadap persistensi laba karena dengan utang yang dimiliki, perusahaan memperoleh tambahan dana untuk membiayai operasional dan mengembangkan perusahaan. Dengan tambahan dana ini diharapkan perusahaan terus meningkatkan pendapatan dan laba yang dihasilkan meningkat. Tingkat utang yang tinggi akan menyebabkan perusahaan meningkatkan persistensi laba dengan tujuan agar investor dan kreditor menilai bahwa kinerja perusahaan baik. Apabila investor memiliki pandangan yang baik terhadap perusahaan, maka perusahaan akan mudah untuk memperoleh tambahan dana, baik dari investor maupun kreditor.

Variabel Ukuran Perusahaan tidak berpengaruh terhadap Persistensi Laba, Hal ini dikarenakan sebagian besar perusahaan Property dan Real estate merupakan perusahaan yang berukuran besar. Selain itu dalam penelitian ini ukuran perusahaan dihitung berdasarkan logaritma dari total aset perusahaan sehingga naik atau turunnya aset dapat menyebabkan berubahnya nilai ukuran perusahaan. Investor menganggap perusahaan yang besar belum tentu memberikan keuntungan yang besar. Efeknya, ukuran perusahaan tidak selalu dapat mencerminkan keadaan yang sebenarnya dari persistensi laba suatu perusahaan. Oleh karena itu, investor lebih memilih melihat kondisi pasar perusahaan secara umum daripada melihat total asetnya.

Arus Kas Operasi, Tingkat Utang dan Ukuran Perusahaan secara simultan berpengaruh signifikan terhadap Persistensi Laba. Sebesar 68,4 \% kontribusi atau pengaruh variabel Arus Kas Operasi $\left(\mathrm{X}_{1}\right)$, Tingkat Utang $\left(\mathrm{X}_{2}\right)$ dan Ukuran Perusahaan $\left(\mathrm{X}_{3}\right)$ secara simultan (bersama-sama) terhadap variabel Persistensi Laba (Y), 
Jurnal Akuntansi \& Perpajakan, Volume 1, No. 2, Januari 2020

sedangkan sisanya sebesar 31,6\% adalah pengaruh faktor lainnya yang tidak diteliti.

Sifat Arus kas Operasi adalah jangka pendek dan cenderung berfluktuasi. Maka, perusahaan harus menjaga arus kas supaya tetap mempengaruhi persistensi laba dimasa yang akan datang supaya para investor tetap melihat bahwa kegiatan operasi perusahaan tetap baik. Pemilik perusahaan jangan khawatir untuk meningkatkan utang, karena tingkat utang yang tinggi akan menyebabkan perusahaan meningkatkan persistensi laba dengan tujuan agar investor dan kreditor menilai bahwa kinerja perusahaan baik. Pada variabel ukuran perusahaan untuk dapat berpengaruh terhadap persistensi laba maka perusahaan harus menambah dan mengelola aset nya dan perusahaan harus semakin giat untuk memperbaiki kinerja penjualan yang mana akan memperbaiki omset penjualan perusahaan. Bagi para calon investor yang akan melakukan investasi di pasar modal, hasil penelitian ini diharapkan dapat berguna sebagai bahan pertimbangan dalam pengambilan keputusan investasi.

\section{DAFTAR PUSTAKA}

Agustin, Laras. 2018. "Pengaruh Aliran Kas dan Perbedaan Antara Laba Akuntansi dengan Laba Fiskal terhadap Persistensi Laba" Jurnal Akuntansi Pascasarjana Universitas Negeri Padang. Padang: Hlm 21

Creswell. 2016. "Pengaruh Volatilitas Arus Kas, Volatilitas Penjualan, Besaran Akrual, dan Financial Leverage terhadap Persistensi Laba Pada Perusahaan Manufaktur yang Terdaftar di Bursa Efek Indonesia”.
Jurnal Akuntansi Pascasarjana Universitas Syiah Kuala. Banda Aceh: Hlm 65.

Damayanti, Dian. 2018. Analisis Laporan Keuangan. Cetakan Ke-2. Bandung: Alfabeta.

Dewi. 2017. "Pengaruh Tingkat Hutang Dan Kepemilikan Manajerial Terhadap Persistensi Laba Pada Perusahaan Manufaktur”. E-Jurnal Akuntansi Universitas Udayana. Denpasar: HIm. 75.

Fahmi, Irfan. 2016. "Pengaruh Tingkat Utang dan Kepemilikan Manajerial Terhadap Persistensi Laba pada Perusahaan Manufaktur". E-Jurnal Akuntansi Universitas Udyana. No. 2 (15) (2016): Hlm. 160-221.

Harahap, Sofyan Safri. 2017. Teori Akuntansi. Jakarta: PT Raja Grafindo Persada.

Ikatan Akuntan Indonesia. 2018. Standar Akuntansi Indonesia. Jakarta: Salemba Empat.

Ingga, Fitria. 2018. Pasar Modal di Indonesia (Pendekatan Tanya Jawab). Jakarta: Salemba Empat.

Kasmir. Analisis Laporan Keuangan. Jakarta: Salemba.

Keiso et al. 2017. Kualitas Laba dalam Perspektif Akrual - Arus Kas dan Pensinyalan Deviden. (Disertasi). Semarang: Universitas Dipenogoro

Murhadi, Werner. Analisis Laporan 
Jurnal Akuntansi \& Perpajakan, Volume 1, No. 2, Januari 2020

Keuangan Proyeksi dan Valuasi

Saham. Jakarta: Salemba Empat.

Nurul. 2019. “Analisis Faktor-Faktor

Penentu Persistensi Laba". Jurnal Akuntansi dan Keuangan Indonesia. Hlm. 43: Salemba.

Nubaety. 2018. “Analisis Perbedaan Laba Akuntansi dan Laba Fiskal Terhadap Persistensi Laba, Akrual dan Aliran Kas pada Perusahaan Perbankan yang Terdaftar di Bursa Efek Jakarta". Jurnal Riset Akuntansi Indonesia: Hlm. 52-57.

Silaen, Sofar. 2018. Metodologi Penelitian Sosial untuk Penulisan Skripsi dan Tesis. Jakarta: In Media.

Sugiyono. 2017. Metode Penelitian kuantitatif, Kualitatif, dan $R \& D$. Bandung: CV Alfabeta.

Weygandt, et al. "Analisa Pengaruh Volatilitas Arus Kas, Volatilitas Penjualan, Tingkat Hutang, Book Tax Gap, dan Tata Kelola Perusahaan Terhadap Persistensi Laba". Tax \& Accounting Review, No.1 (4) (2016): Hlm. 37-53. 